ЧУБАНЬ

Вікторія Сергївна

sv.yak@ukr.net

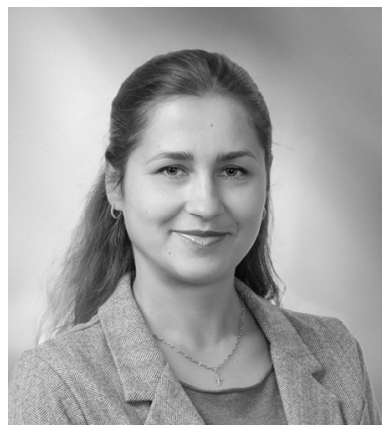

к.е.н., доиент, Черкаський інститут пожежної безпеки імені Героїв

Чорнобиля Начіонального університету ичивільного захисту України
ПАСИНЧУК

Кирило Миколайович

Pasynchuk_Kyrylo@chipb.org.in

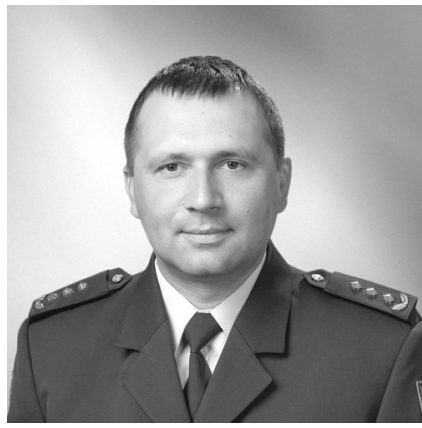

к.пед.н., доиент кафедри, Черкаський інститут пожежної безпеки імені Героїв Чорнобиля Національного університету цивільного захисту Украӥни
КРІЧКЕР

Ольга Юхимівна medkoin@ukr.net

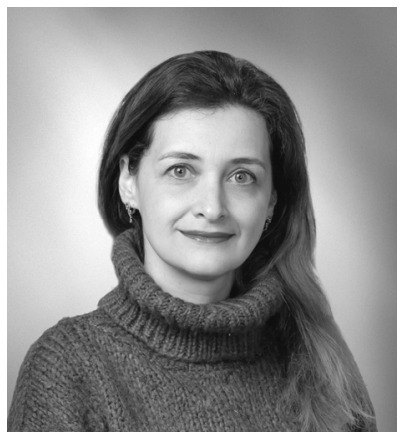

к.пед.н., доиент кафедри, Черкаський інститут пожежної безпеки імені Героїв Чорнобиля Національного університету ичивільного захисту Украӥни

УДК 330.4

\title{
PROBLEMS AND FURTHER DEVELOPMENT OF FUNCTIONING OF SPECIALIZED ANTI- CORRUPTION AGENCIES
}

\section{ПРОБЛЕМИ ТА НАПРЯМКИ УДОСКОНАЛЕННЯ ФУНКЦІОНУВАННЯ СПЕЦАЛІЗОВАНИХ АНТИКОРУПЦІЙНИХ ОРГАНІВ}

\author{
DOI: https://doi.org/10.37634/efp.2020.9.6
}

CHUBAN Viktoriia Serhïvna - PhD in Economics, Associate Professor, Civil Protection Sphere in Cherkasy Institute of Fire Safety after Chornobyl Heroes of NUCD in Ukraine

PASYNCHUK Kyrylo Mykolaiovych - PhD in Pedagogy, Civil Protection Sphere in Cherkasy Institute of Fire Safety after Chornobyl Heroes of NUCD in Ukraine

\section{KRICHKER Olha Yukhymivna - PhD in Pedagogy, Civil Protection Sphere in Cherkasy Institute of Fire Safety after Chornobyl} Heroes of NUCD in Ukraine

The article focuses on the problem of the institutional support for combating corruption. The scatter and dispersion in the anticorruption functions among the law enforcement agencies are considered to be a significant component of the problem of the institutional support for combating corruption. The functioning of some specialized anti-corruption agencies is also analyzed in the article. Priority areas for improvement of the Specialized Anti-Corruption Prosecutor's Office and National Anti-Corruption Burea of Ukraine are singled out. It is justified that the functioning of The Specialized Anti-Corruption Prosecutor's Office is a special law enforcement activity to combat corruption in public authorities and local self-government. It is concluded that due to the possibility of ambiguous insight into the system of agencies implementing measures on preventing and combating corruption, the legislation should clearly define this notion in a single legal act with a clear division of responsibilities and forms of interaction, as well.

Furthermore, the authors of the article develop proposals on ways to combat corruption in Ukraine, including legislative, and organizational and managerial ideas concerning the implementation of the experience in preventing and combating corruption following the example of foreign countries. In particular, the main priorities of the state anti-corruption policy in Ukraine should be defined in a special regulation - the Anti-Corruption Strategy. The previous Anti-Corruption Strategy and the State Program for its implementation expired in December 2017, so Ukraine should have started the year 2018 with new versions of these documents. For more than two years, Ukraine has not had a major strategic document in the field of corruption prevention. The draft Law on AntiCorruption Strategy for 2018-2020 was withdrawn on August 29, 2019.

$$
* * *
$$

В статье затронута проблема институционального обеспечения противодействия коррупции. Также в статье проанализирована деятельность некоторых специализированных антикоррупционных органов. Bыделены приоритетные направления совершенствования деятельности специализированной антикоррупционной прокуратуры и Национального антикоррупиионного бюро Украины. Сделан вывод, что несмотря на возможность неоднозначной трактовки системы органов, осуществляюших меры по предотвращению и противодействию коррупции, в законодательстве следует четко определить ее в едином нормативно-правовом акте с четкими распределением их обязанностей, а также форм взаимодействия. В статье получили дальнейшее развитие предложения по направлениям преодоления коррупции в Украине, включая законодательные и организачионно-управленческие идеи внедрения в Украине зарубежного опьта предупреждения и противодействия коррупции по примеру зарубежных стран. 
У статті порушено проблему інституційного забезпечення протидії корупиії. Визначено, щңо важливою складовою проблеми інституційного забезпечення протидії корупції є розпороченість функиії запобігання корупиії між правоохоронними органами. Також у статті проаналізовано діяльність деяких спеціалізованих антикорупційних органів. Виокремлено пріоритетні напрями вдосконалення діяльності спещіалізованої антикорупціійної прокуратури та Національного антикорупційного бюро України. Обгрунтовано, щцо функціонування спеціалізованої антикорупційної прокуратури $\epsilon$ особливим видом правоохоронної діяльності із протидї корупиї в органах державної влади та місцевого самоврядування.

Зроблено висновок, щео зважаючи на можливість неоднозначного трактування системи органів, щзо здійснюють заходи стосовно запобігання та протидї корупиії, у законодавстві слід чітко визначити ії в єдиному нормативно-правовому акті з чіткими розподілом їх обов 'язків, а також форм взаємодії.

У статті набули подальшого розвитку пропозиції стосовно напрямків подолання корупиії в Україні, включаючи законодавчі та організаційно-управлінські ідеї впровадження в Украӥні зарубіжного досвіду запобігання і протидї корупиіі за прикладом зарубіжних країн. Зокрема, основні пріоритети державної антикорупційної політики в Україні повинні визначатися у спеціальному нормативному акті - Антикорупційній стратегії. Термін дії попередніх Антикорупційної стратегії та Державної програми з ї̈ реалізації спливли у грудні 2017 р., а тому новий 2018 р. Україна мала б розпочати 3 новими редакиіями ичих документів. Вже понад два роки в Україні немає основного стратегічного документу у сфері запобігання корупиії. Проект Закону про Антикорупиійну стратегію на 2018-2020 рр. 29 серпня 2019 р. було відкликано.

Keywords: anticorruption strategy, corruption, the Specialized Anti-Corruption Prosecutor's Office, National AntiCorruption Burea of Ukraine, Specialized Anti-Corruption bodies

Ключевые слова: антикоррупиионная стратегия, коррупция, специиализиованная антикоррупционая прокуратура, Национальное антикоррупционое бюро Украины, специализированные антикоррупционные органы

Ключові слова: антикорупційна стратегія, корупція, спеціалізована антикорупиіійна прокуратура, Національне антикорупиійне бюро України, спеціалізовані антикорупційні органи

\section{INTRODUCTION}

According to opinion surveys, about half of citizens of Ukraine are concerned about the level of corruption in the country, as this phenomenon undermines the foundations of the state system and leads to violations of the rights and freedoms of citizens. Thus, for the last decade, citizens have considered Ukraine one of the most corrupted in the world. Total corruption has an extremely negative effect on the realization of Ukraine's European aspirations.

The scientific and theoretical bases of the article are the works of such scientists as Ye.M. Blazhivskyi, Ye.V. Vandin, V.M. Horshenov, V.V. Dolezhan, D.A. Kerimov, S.V. Kivalov, M.I. Koziubra, I.M. Koziakov, M.V. Kosiuta, O.M. Lytvak, H.V. Maltsev, S.S. Miroshnychenko, S.H. Mishchenko, N.M. Onishchenko, N.O. Rybalka, M.V. Rudenko, V.V. Sukhonos, Yu.A. Tykhomyrov, R.M. Shestopalov, M.K. Yakymchuk and others. A lot of previous studies in this area have largely lost relevance, although they have retained their relevance for an indepth study of the problems of overcoming corruption. In this regard, the study of ways of improving of the functioning of specialized anti-corruption agencies is an urgent and important task of legal science.

The PURPOSE of the paper is to analyze the activities of some specialized anti-corruption bodies and identifying priority areas for improving the activities of The Specialized Anti-Corruption Prosecutor's Office and The National Anti-Corruption Bureau of Ukraine.

\section{RESEARCH METHODS}

The following methods of research are used in the study: analysis and synthesis, comparison, system and generalization analysis, inductive inference etc.

\section{RESULTS}

A qualitatively new level in the field of preventing and combating corruption has been achieved thanks to the implementation of basic anti-corruption laws, which have strengthened legal liability for violating the requirements for declaring income and property in the context of administrative and criminal law.

It is worth noting that an important component of the problem of institutional support for combating corruption is the scatter and dispersion of the function of preventing corruption among law enforcement agencies. Analyzing the legislation that was in force before, it can be concluded that this function (as well as the fight and counteraction) was entrusted to the relevant departments: Ministry of Internal Affairs of Ukraine; tax police; Security Services of Ukraine; bodies of the Prosecutor's Office of Ukraine; Military Law Enforcement Service in the Armed Forces of Ukraine; other bodies and units created to fight corruption in accordance with the current legislation [2]. Let's consider the activities of the special anti-corruption agencies of Ukraine.

The State Bureau of Investigation (SAP) is a law enforcement agency, Ukraine has been waiting for more than 20 years. As soon as it was created, the functions of pre-trial investigation were transferred from the prosecutor's office to the SAP, and the function of supervision remained with the prosecutor's office. This approach is the standard of objective and impartial investigation. The SAP is under the jurisdiction of top officials, judges, law enforcement officials, and those who have committed war crimes. That is, in most cases, these are people who have the opportunity to influence the course of criminal proceedings and avoid punishment. In 2018 the process of establishing of the work of the SAP continued and the completion resulted into more than 500 employees joined to the organization, 285 of which as investigators. A regional network was also built: territorial State Bureau of Investigation offices were opened in Kyiv, Kramatorsk, Lviv, Melitopol, Mykolaiv, Poltava, and Khmelnytsky, and their regulations and annual programs were approved.

As of January 1, 2020, the SAP, as a law enforcement 
agency, was conducting a pre-trial investigation of more than 2,400 criminal proceedings, 569 of which were initiated by the Bureau's investigators. 70 criminal proceedings were sent to court [4].

The National Agency for the Detection, Investigation and Management of Assets Obtained from Corruption and Other Crimes (ARMA) was established to address the problem of ineffective disclosure of assets obtained through crime and corruption. The establishment and start-up of the Agency was one of the key requirements of the Visa Liberalization Action Plan in the framework of the visa-free dialogue between Ukraine and the EU. During 2018, measures were taken to complete the process of ensuring the functional capacity of ARMA to perform the functions assigned to it to identify, search and manage assets. In particular, the central office of the Agency was staffed, and six territorial offices were established.

In 2018, for the first time, a full-fledged process of managing the seized assets was carried out: from the acceptance into the ARMA management up to the return of these assets to their owner. Thus, various types of seized assets (real estate, vehicles, and corporate rights) were transferred to the managers and the profitability of the management of these assets was ensured at a level that ensures their maintenance for further confiscation or return to the owners.

According to the results of 2019, thanks to ARMA, more than UAH 9 million of revenues returned from the management of seized assets to the State Budget of Ukraine, and the sale of seized assets brought an additional UAH 3.1 million.

The efficiency of the work of the National Agency for the Prevention of Corruption in checking the declarations of officials and establishing the timeliness of submission of declarations and notifications of significant changes in property status increased, as well. Thus, in 2018, the number of the decisions on the results of full inspections of declarations increased more than three times compared to 2017 and reached 472, the number of drawn up and sent to court protocols on administrative offenses as a result of financial control increased almost sevenfold - to 310 , and the number of substantiated conclusions sent to law enforcement agencies for pre-trial investigation increased 12 times reaching 243.

In order to increase the productivity of full verification of declarations, the National Agency for the Prevention of Corruption introduced a system of verification of electronic declarations [3]. The information and telecommunication system of logical and arithmetic control of declarations was adopted for permanent (industrial) operation, the Rules on the basis of which such control took place were finalized and approved, the necessary changes to the Procedure were made establishing the procedure for full verification of declarations.

The National Anti-Corruption Bureau of Ukraine (NABU) is a state law enforcement body that is responsible for preventing, detecting, terminating, investigating and disclosing corruption offenses within its jurisdiction, as well as preventing the commission of new ones. The task of NABU is to combat criminal corruption offenses committed by senior officials authorized to perform the functions of state or local self-government that pose a threat to national security.

The Specialized Anti-Corruption Prosecutor's Office in Ukraine (SAP) is an independent structural subdivision of the General Prosecutor's Office of Ukraine, which is responsible for: supervision of compliance with the law during the operational and investigative activities of the pre-trial investigation by the National Anti-Corruption Bureau of Ukraine; support for public prosecution in relevant proceedings; representation of the interests of a citizen or the state in court in cases provided by law and related to corruption or corruption-related offenses [1].

The second half of 2019 was a period of intensification of the fight against top corruption in Ukraine. In the second half of 2019, 84 people were detected and reported as suspects, which was more than for the whole previous year. The lion's share of those prosecuted were high-ranking officials, judges, former deputies, directors of state-owned enterprises, etc. The achieved results was the result of a number of factors including the work of the investigation in previous periods, and the coordinated cooperation of NABU and SAP with other law enforcement agencies, in particular, the Security Service of Ukraine, the Prosecutor General's Office, and state executive institutions.

Among the successful investigations, it is worth noting such high-profile cases as: UAH 18.87 billion in damage to electricity consumers due to the introduction of the so-called Rotterdam + formula, seizure of National Guard property for over UAH 80 million, loans of Sberbank and the National Bank of Ukraine. In total, in the second half of 2019, the National Bureau and the CAP launched investigations in 674 criminal proceedings, which are 141 proceedings more than in the previous reporting period [4].

Among the most priority recommendations for taking measures outside NABU, we would like to offer: avoidance of amendments to the legislation governing the work of NABU and SAP without prior thorough consultations with NABU, SAP, other law enforcement agencies, society, experts and other stakeholders; amendments to Art. 263 of the Criminal Procedural Code of Ukraine on granting NABU the authority to independently withdraw information from communication channels; change of the status of the SAP, its transformation into an autonomous body of the Prosecutor's Office and limitation of the powers of the Prosecutor General in terms of organizing the work of the SAP, decision-making on the number and organizational structure; improving the working conditions and capacity of the court considering the NABU petition at the pretrial investigation stage.

Given the possibility of ambiguous interpretation of the system of agencies implementing measures to prevent and combat corruption, the legislation should clearly define it in a single legal act with a clear division of responsibilities and forms of interaction. This will ensure efficiency and openness in the fight against corruption and will make it impossible for any of the agencies to perform its function or duplicate it in relation to other bodies.

Thus, it is worth summarizing that during several years of NABU's operation there have been many scandals against corruption at the highest level (for example, highprofile cases involving the arrest of Arsen Avakov's son or inspection of Petro Poroshenko's company), and this 
body is most effective in preventing and combating corruption but would be useful to see a different level of its progress and significant changes in our society. In particular, it would be appropriate to expand the competence to interact with other bodies implementing measures to prevent and combat corruption. And to gradually shift responsibilities between the various levels in order to prevent and combat corruption at all levels, not just the highest [4].

An important condition for overcoming corruption in our country is the adoption of the regulations allowing for the application of real, definite measures on preventing, detecting and stopping corruption offenses in law enforcement. However, the analysis of certain provisions of the Law of Ukraine On the National Anti-Corruption Bureau of Ukraine does not give an answer to the logical question of how to quickly and objectively combat corruption in Ukraine. At the same time, some provisions of this legislative act are in conflict. In particular, the main priorities of the state anti-corruption policy in Ukraine should be defined in a special legislative act - the Anti-Corruption Strategy.

This is an important document for fighting corruption in Ukraine, as it defines the main priorities of the state anti-corruption policy for a certain period and is the only basis for developing a national action plan on preventing corruption - the State Program for Anti-Corruption Strategy.

Unlike the Anti-Corruption Strategy, such a program contains specific measures to address local issues and achieve the ultimate goal, the timing of their implementation and the responsible authorities. Also, the State Program is a basic document for the development of anti-corruption programs of each state body, local government and other institutions. The validity of the previous Anti-Corruption Strategy and the State Program for its implementation expired in December 2017; therefore, Ukraine should have worked out the new versions of these documents [2].

For more than two years, Ukraine has not had a major strategic document in the field of preventing corruption. The draft Law on Anti-Corruption Strategy for 20182020 was withdrawn on August 29, 2019. Therefore, anticorruption bodies act in an unbalanced and ineffective manner, while other state bodies and local self-government bodies carry out the anti-corruption measures that they intuitively consider appropriate. Or stand still.

\section{CONCLUSIONS}

Thus, we state that an important component of the problem of the institutional support for combating corruption is the dispersion of the function of preventing corruption between the law enforcement agencies.

The Specialized Anti-Corruption Prosecutor's Office is a kind of law enforcement activity to combat corruption in public authorities and local self-government. Given the possibility of ambiguous interpretation of the system of bodies which implement measures on preventing and combating corruption, the legislation should clearly define it in a single legal act with a clear division of responsibilities and forms of interaction.

The main priorities of the state anti-corruption policy in Ukraine should be defined in a special legislative act the Anti-Corruption Strategy. The previous Anti-Corruption Strategy and the State Program for its implementation expired in December 2017, thus new versions of these documents are required. For more than two years now, Ukraine has not had a major strategic document in the field of preventing corruption. The draft Law on AntiCorruption Strategy for 2018-2020 was withdrawn on August 29, 2019.

\section{$\underline{\text { References }}$}

1. Valdin Ye.V. Organizational and legal principles of activity of the specialized anti-corruption prosecutor's office of Ukraine: abstract ... PhD in legal sciences: 12.00.10. Odesa, 2017. 20 p. (in Ukrainian).

2. Liubavin Yu.O. Ways of improvement of anti-corruption legislation of Ukraine in the context of the foreign experience of defining corruption phenomena. May legal readings. Cherkasy, 2020. pp. 276-278. (in Ukrainian).

3. Obrusna S.Yu., Pasynchuk K.M., Chuban V.S. Organizational and legal aspects of financial security of Ukraine. Actual problems of domestic jurisprudence. Dnipro, 2019. № 5. pp. 99-103. (in Ukrainian).

4.Chuban V.S., Kricher O.Yu. Anti-corruption strategy as the basis of anti-corruption fight. The role of integration processes in the formation of national legal systems. Kherson, 2020. Vol. II. pp. 52-54.

\section{Список використаних джерел}

1. Вандін С.В. Організамійно-правові засади діяльності спеціалізованої антикорупиійної прокуратури Украӥни: автореф. дис. ... канд. юрид. наук: 12.00.10; Нач. ун-т "Одес. юрид. акад.". Одеса, 2017. 20 c.

2. Любавін Ю.О. Напрямки вдосконалення антикорупиійного законодавства Украӥни в контексті зарубіжного досвіду визначення корупчійних явищ. Травневі правові читання: Матеріали I Всеукраӥнської науково-практичної конференції здобувачів та викладачів закладів вищої освіти. (Черкаси, 7 травня 2020). Черкаси, 2020. С. 276-278

3. Обрусна С.Ю., Пасинчук К.М., Чубань В.С. Організаиійно-правові аспекти фінансової безпеки України. Науковий збірник «Актуальні проблеми вітчизняної юриспрудениї» Дніпровського національного університету імені Олеся Гончара. Дніпро: Дніпровський начіональний університет імені Олеся Гончара, 2019. № 5. С.99-103

4. Chuban V.S., Kricher O.Yu. Anti-corruption strategy as the basis of anti-corruption fight. Роль інтеграчійних процесів у формуванні національних правових систем. Матеріали I Міжнародної науково-практичної інтернетконференції (10-11 квітня 2020 р.). Херсон: Херсонський держсвний університет, 2020. Том II. С. 52-54 